\title{
Evaluation of two palatoplasty techniques in patients with cleft palate
}

\author{
Fábio Ricardo Loureiro Sato ${ }^{* 1}$, Magno Liberato da Silva ${ }^{2}$ and Roger William Fernandes Moreira ${ }^{3}$ \\ Maxillofacial Surgeon, Face Defects Hospital - Brazilian Red Cross, São Paulo, Brazil \\ ${ }^{2}$ Resident of Oral and Maxillofacial Surgery, Face Defects Hospital - Brazilian Red Cross, São Paulo, Brazil \\ ${ }^{3}$ Chief of Oral and Maxillofacial Surgery Department, Face Defects Hospital - Brazilian Red Cross, São Paulo, Brazil
}

${ }^{1}$ Assistant Professor, Oral and Maxillofacial Surgery Area, State University of São Paulo - UNESP, College of Dentistry, São José dos Campos and Oral and

\begin{abstract}
Introduction: The aim of this study was to make a comparative evaluation between two palatoplasty techniques - Von Langenbeck and Veau-Wardill-Kilner - by evaluating if such techniques succeed in closing the palatine fissure and correcting hypernasality.

Methods: Patients undergoing palatoplasty surgery in the period from 2011 to 2014 by means of the Oral and Maxillofacial Surgery Department of the Hospital of Face Defects were selected and requested to undergo a new evaluation. The medical records of patients who attended the new evaluation were assessed as to the number of surgeries performed and patients undergoing physical examination to check for the presence of fistulas, and they were asked about the improvement in hypernasality.

Results: 10 out of the total number of operated patients attended for evaluation, and none of them had an oronasal fistula. The Von Langenbeck technique proved to be effective in $67 \%$ of the cases in closing the gap in the first surgery, whereas the Veau-Wardill-Kilner technique was effective in $50 \%$ of the cases. Concerning the correction of hypernasality, Von Langenbeck was effective in $67 \%$ of the case, and Veau-Wardill-Kilner, in $75 \%$.

Conclusion: The Von Langenbeck technique was more effective in closing the Cleft Palate and Cleft Lip, while Veau-Wardill-Kilner technique was effective in correcting hypernasality.
\end{abstract}

\section{Introduction}

Cleft lip and cleft palate are the most common congenital anomalies affecting the face, with an incidence of approximately 0.5 individuals every 1,000 live births [1]. This malformation can present itself in many ways, involving lip, palate or both structures.

Cleft lip usually has a greater aesthetic and social impact; however, cleft palate has the greatest functional impacts.

The goals of palatoplasty are, of course, in addition to closing the oral and nasal communication, to promote an intelligible speech, as close as possible to the normal range, and prevent interference with the maxillary growth (which, in the future, would entail the need for orthopedic maxillary expansion and subsequent orthognathic surgery).

During palatoplasty, care is essential to reposition anatomically the levator muscle of the soft palate, which is inserted into the posterior border of the hard palate with longitudinally directed fibers. The disinsertion of the fibers and repositioning thereof in cross direction, uniting them with the fibers across the fissure, allows sphincteric and lifting function of the palatine musculature required for oronasal occlusion [2].

There are several palatoplasty techniques described in the literature, the choice based on several criteria: type of fissure, fissure extension, preference and technical skill of the surgeon.

Within the available techniques, the two most used palatoplasty techniques for patients with cleft palate by our service are the Von
Langenbeck and de Veau techniques with Wardill-Kiner modifications, as in other services in Brazil, according to a survey of Paranaíba et al. [3].

The Von Langenbeck technique of was described initially in 1861[4], and advocated the use of mucoperiosteais bipedicle flaps, which is still the most used palatoplasty technique nowadays (Figures 1 and 2). De Veau Palatoplasty with two flaps associated with "pushback" procedures with elongation of the palate in VY as recommended by
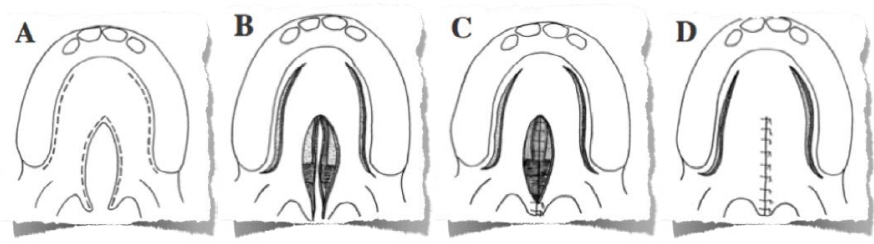

Figure 1. Palatoplasty in accordance with Von Langenbeck Technique (1861).

Correspondence to: Dr. Fábio Ricardo Loureiro Sato, Oral and Maxillofacial Surgery Area, State University of São Paulo - UNESP, College of Dentistry - São José dos Campos, Av. Eng. Francisco José Longo, 777 - 12245-000 São José dos Campos - SP - Brazil; Phone/Fax: +55 12 3947-9000; E-mail: fabio.sato@ict.unesp.br

Key words: palatoplasty, cleft lip, cleft palate, surgery

Received: September 17, 2016; Accepted: October 19, 2016; Published: October 22, 2016 
Wardill [5] and Kilner [6] is also quite popular, because theoretically would decrease the possibility developing velopharyngeal dysfunction (Figures 3 and 4).

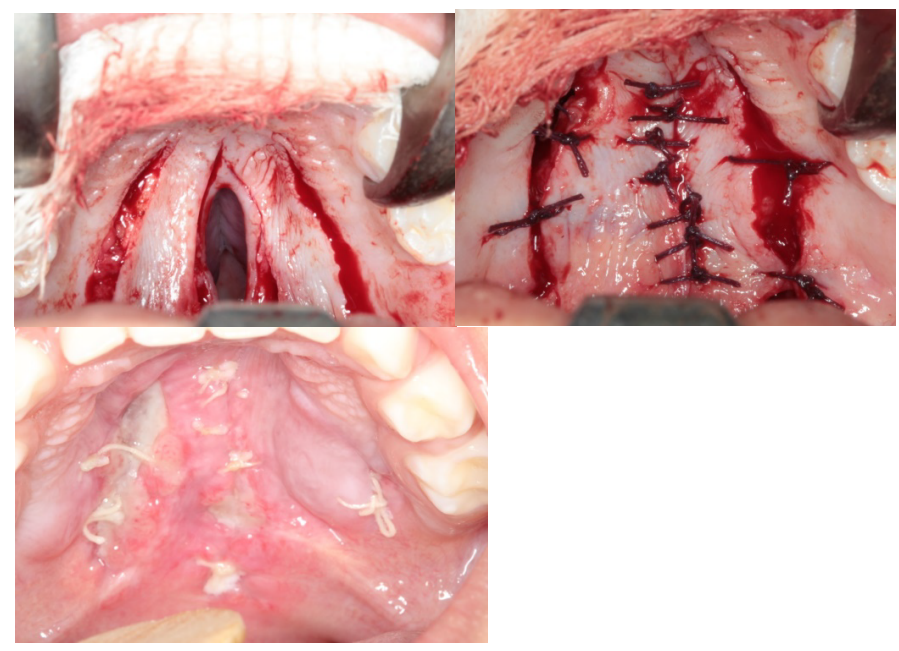

Figure 2. Palatoplasty of a complete post-foramen cleft palate with Von Langenbeck Technique (1861)
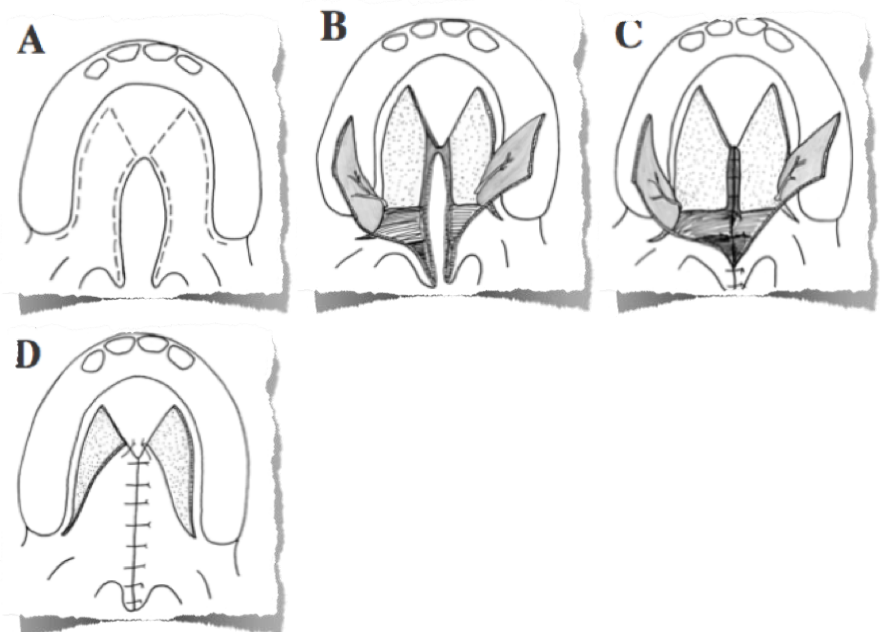

Figure 3. Palatoplasty in accordance with Veau-Wardill-Kilner Technique (1937)

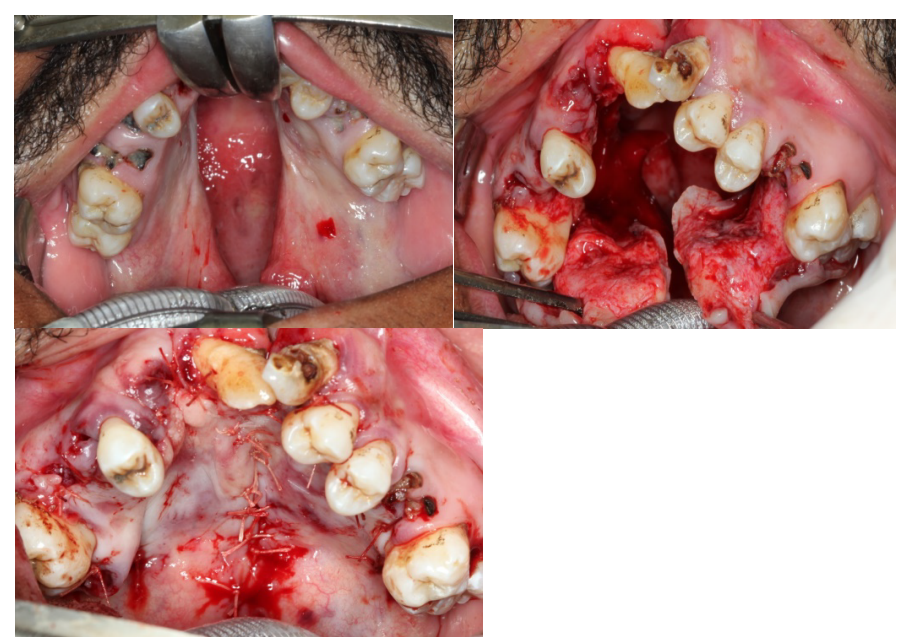

Figure 4. Palatoplasty of a complete post-foramen cleft palate with Veau-Wardill-Kilner Technique (1937).
Table 1. Closing time of the cleft palate according to the surgical technique.

\begin{tabular}{|l|l|l|l|}
\hline Technique & Patients Operated & Closure in & Closure in \\
\cline { 3 - 4 } & & First Time & Second Time \\
\hline Veau-Wardill-Kilner & 04 patients & 02 patients & 02 patients \\
\hline Von Langenbeck & 06 patients & 04 patients & 02 patients \\
\hline TOTAL & 10 patients & 06 patients & 04 patients \\
\hline
\end{tabular}

Although widely used, to date, few studies evaluated the effectiveness in closing of palatine fissure of both techniques in a comparative way. Thus, the aim of this study is to conduct a retrospective study of the effectiveness of these techniques as to two criteria: presence of residual fistula and improved hypernasality from the patient's point of view.

\section{Methods}

A survey of medical records of patients undergoing palatoplasty procedure by means of the Oral and Maxillofacial Surgery Department of the Hospital of Face Defects of the Brazilian Red Cross was initially conducted in the period from 2011 to 2014.

Patients were then asked to return for evaluation, in order to check the presence of possible remaining oronasal fistula and requested to assess subjectively the improvement in hypernasality.

\section{Results}

10 patients out the total of patients operated in this period returned and were again evaluated by the researchers and asked about the improvement in velopharyngeal function. 8 out of these 10 patients were female and two were male, with an average age of 14 years and 5 months old. Concerning the type of technique used, 6 were Von Langenbeck and 4 were Veau-Wardill-Kilner. All patients had no residual fistulas after surgical procedures.

After analysis of the medical records, we verified that 6 patients had their fissure closed in the first surgical period, and other 4 required a second surgical period, due the permanence of oronasal fistula.

When we compared both techniques as to the quantity of surgeries to close cleft palate, we identified that the Von Langenbeck technique presents a better closing index on the first surgical time (67\%), when compared to the Veau-Wardill-Kilner technique (50\%).

However, when asked about the improvement in hypernasality, $75 \%$ of patients operated by means of Veau-Wardill-Kilner technique showed improvement, while for Von Langenbeck technique the number was $67 \%$.

\section{Discussion}

This study allowed to evaluate the two primary goals of the palatoplasty techniques, which is the closing of the oral and nasal communication and the normal development of speech.

Other studies in the literature also compared palatoplasty techniques. Williams et al. [7] compared Von Langenbeck and Langenbeck e Furlow techniques, the latter being a technique that uses the principles of zetaplasty to stretch the soft palate. This work also demonstrated a lower presence of fistula after the first surgery by Von Langenbeck (14\%), when compared to Furlow technique (23\%). However, as in the data obtained in our study, the improvement in hypernasality was better in the group that used Furlow technique (82\%) when compared to Von Langenbeck technique (71\%).

According to Chen et al. [8], palatoplasty techniques that use the 
concepts of pushback to stretch the soft palate has the advantage of better results in relation to the correction of velopharyngeal dysfunction; however, as they generate greater tensions in the tissues, there is a greater chance of appearing fistulas in the postoperative period.

Lage et al. [9] compared two palatoplasty techniques to concepts of pushback (Veau and Furlow) and demonstrated that there is no difference between both techniques on the presence of complications in the postoperative period. Paniagua et al. [10] also found a similar result comparing these two pushback techniques.

\section{Conclusion}

Based on the results of this study, we verified that Von Langenbeck palatoplasty technique reduces the chance of residual fistula after the first surgical procedure; however, Veau-Wardill-Kilner technique is more effective in preventing velopharyngeal dysfunction.

\section{References}

1. Murray JC (2002) Gene/environment causes of cleft lip and/or palate. Clin Genet 61: 248-256. [Crossref]

2. Berkowitz, S (2013) Cleft Lip and Palate: Diagnosis and Management. New York: Springer.
3. Paranaíba LM, Almeida Hd, Barros LM, Martelli DR, Orsi Júnior JD, et al. (2009) Current surgical techniques for cleft lip-palate in Minas Gerais, Brazil. Braz J Otorhinolaryngol 75: 839-843. [Crossref]

4. Von Langenbeck B (1861) Die uranoplastik mittelst ablosung des mucoes-periostalen gaumenuberzuges. Arch Klin Chir 2: 205-87.

5. Wardill WEM (1937) The technique of operation for cleft palate. Br J Surg 25: 117-130.

6. Kilner TP (1937) Cleft lip and palate repair technique. St Thomas Hosp Rep 2: 127-131

7. Williams WN, Seagle MB, Pegoraro-Krook MI, Souza TV, Garla L, et al. (2011) Prospective clinical trial comparing outcome measures between Furlow and von Langenbeck Palatoplasties for UCLP. Ann Plast Surg. 66:154-163. [Crossref]

8. Chen PK, Wu JT, Chen YR, Noordhoff MS (1994) Correction of secondary velopharyngeal insufficiency in cleft palate patients with the Furlow palatoplasty. Plast Reconstr Surg. 94: 933-941. [Crossref]

9. Lage RR, Ferreira BM, Nassif AD, Rodrigues HLR, Heitor BS (2010) Complicações agudas em palatoplastias: estudo comparativo prospectivo entre as técnicas de Veau modificada e de Furlow. Rev Bras Cir Craniomaxilofac 13: 139-142.

10. Paniagua LM, Collares MVM, Costa SS (2010) Estudo comparativo de três técnicas de palatoplastia em pacientes com fissura labiopalatina por meio das avaliações perceptivo-auditiva e instrumental. Arq Int Otorrinolaringol 14: 18-31.

Copyright: $(02016$ Sato FRL. This is an open-access article distributed under the terms of the Creative Commons Attribution License, which permits unrestricted use, distribution, and reproduction in any medium, provided the original author and source are credited. 